\title{
The problem of seismic potential assessment: Case study of the unexpected earthquake of 7 September 1999 in Athens, Greece
}

\author{
Gerassimos A. Papadopoulos ${ }^{1}$, Athanassios Ganas ${ }^{1}$, and Spyros Pavlides ${ }^{2}$ \\ ${ }^{1}$ Institute of Geodynamics, National Observatory of Athens, 11810 Athens, Greece \\ ${ }^{2}$ Department of Geology, Aristotelian University of Thessaloniki, 54006 Thessaloniki, Greece
}

(Received April 10, 2000; Revised September 14, 2001; Accepted September 28, 2001)

\begin{abstract}
Lessons learned form the disastrous earthquake $\left(M_{W}=5.9\right)$ that hit the metropolitan area of Athens, Greece, on 7 September 1999, are examined particularly as for the seismic potential considered before the earthquake occurrence. A general belief was created in the past decades that the seismic potential in Athens was very low. Fault plane solutions of the 1999 shock indicate that it was associated with a normal fault trending WNW-ESE and dipping to SW. Field geological observations conducted after the event in the Fili neotectonic fault, situated at 15$20 \mathrm{~km}$ to the north of Athens, imply that it has possibly been the seismogenic structure of the main rupture, and that it reactivated in very recent geological times. Archaeoseismological observations performed in the ancient Fili Fort, revealed repaired structural damage that was very likely caused by an earthquake occurring in palaeochristianic or Byzantine times. From a new catalogue of historical earthquakes it results that the main events of 1705,1805 and 1889 could be tentatively located within a distance of $\sim 30 \mathrm{~km}$ from Athens although the little macroseismic information available makes their locations quite uncertain. During the instrumental period of observation, only few small shocks were recorded in the Athens region. It is obvious that should a research effort had been undertaken before the 1999 earthquake, certainly it would be concluded that at least one strong earthquake took place in historical times in the broad region affected in 1999, and that the Fili fault is active and is capable to produce strong shocks in the future. However, such a study was never conducted by the scientific community beforehand.
\end{abstract}

\section{Introduction}

Earthquakes are major natural hazards in European regions like the Balkan Peninsula, Italy, parts of Russia, etc. Many cases of extensive loss of human life and injury as well as tangible and intangible social and economic losses have been reported (e.g. Shebalin et al., 1974; Ganse and Nelson, 1979; Tiedemann, 1991). Dramatic conditions were created by catastrophic earthquakes in capital cities, like Bucharest in 1977, and Athens in 1981 and mainly in 1999. A comparison of earthquake economic losses with the gross national product (GNP) of the country shows that the 1977 Bucharest (Romania), 1980 Campania (Italy) and 1986 Kalamata (Greece) catastrophic earthquakes created material losses equal to $3.0 \%, 6.8 \%$ and $2.0 \%$ of the GNP of the respective countries (Coburn and Spence, 1992).

The reliable estimation of the seismic potential is a cornerstone for the seismic risk reduction in any earthquakeprone area. However, no single methodology has emerged for the seismic potential evaluation. In this paper several approaches developed worldwide are very briefly reviewed. Then, the earthquake $\left(M_{W}=5.9\right)$ of 7 September 1999 that hit Athens, the capital city of Greece, is examined as a particular case of an unexpected disastrous event. This earthquake has been quite characteristic in that it occurred in a region traditionally considered as being of very low seis-

Copy right(c) The Society of Geomagnetism and Earth, Planetary and Space Sciences (SGEPSS); The Seismological Society of Japan; The Volcanological Society of Japan; The Geodetic Society of Japan; The Japanese Society for Planetary Sciences. mic potential. Therefore, an effort was made to respond on three main questions: (1) Why the particular region of the 7 September 1999 earthquake was considered in the past as of very low seismic potential? (2) How new observations collected after the earthquake occurrence affect the seismic potential assessment? (3) What a research effort undertaken before the 1999 event would have revealed about the seismic potential?

\section{Definitions of Seismic Potential: A Brief Review} The concept of seismic gap (Fedotov, 1965; Mogi, 1968; Kelleher et al., 1973) has been among the very first ideas for the seismic potential assessment. Since that time the seismic gap hypothesis was further defended (e.g. McCann et al., 1979; Nishenko and McCann, 1981; Nishenko, 1985, 1989, 1991; Nishenko and Sykes, 1993) or critisized (e.g. Kagan and Jackson, 1991). At the same time a variety of other approaches were also proposed including stochastic (e.g. Cornell, 1968; McGuire, 1978; Nishenko, 1989, 1991; see also Schenk, 1989 and McGuire, 1993 for reviews), deterministic (e.g. Iida, 1965; Slemmons, 1977; McCann et al., 1979; Wyss, 1979) or both (e.g. Wesnousky et al., 1984; Working Group on California Earthquake Probabilities, 1990). Wallace et al. (1984) suggested that the term earthquake potential can be expressed either numerically or verbally according to a variety of schemes. In fact, in seismogenic regions of the world a variety of methodological schemes have been tested including seismicity analysis, 


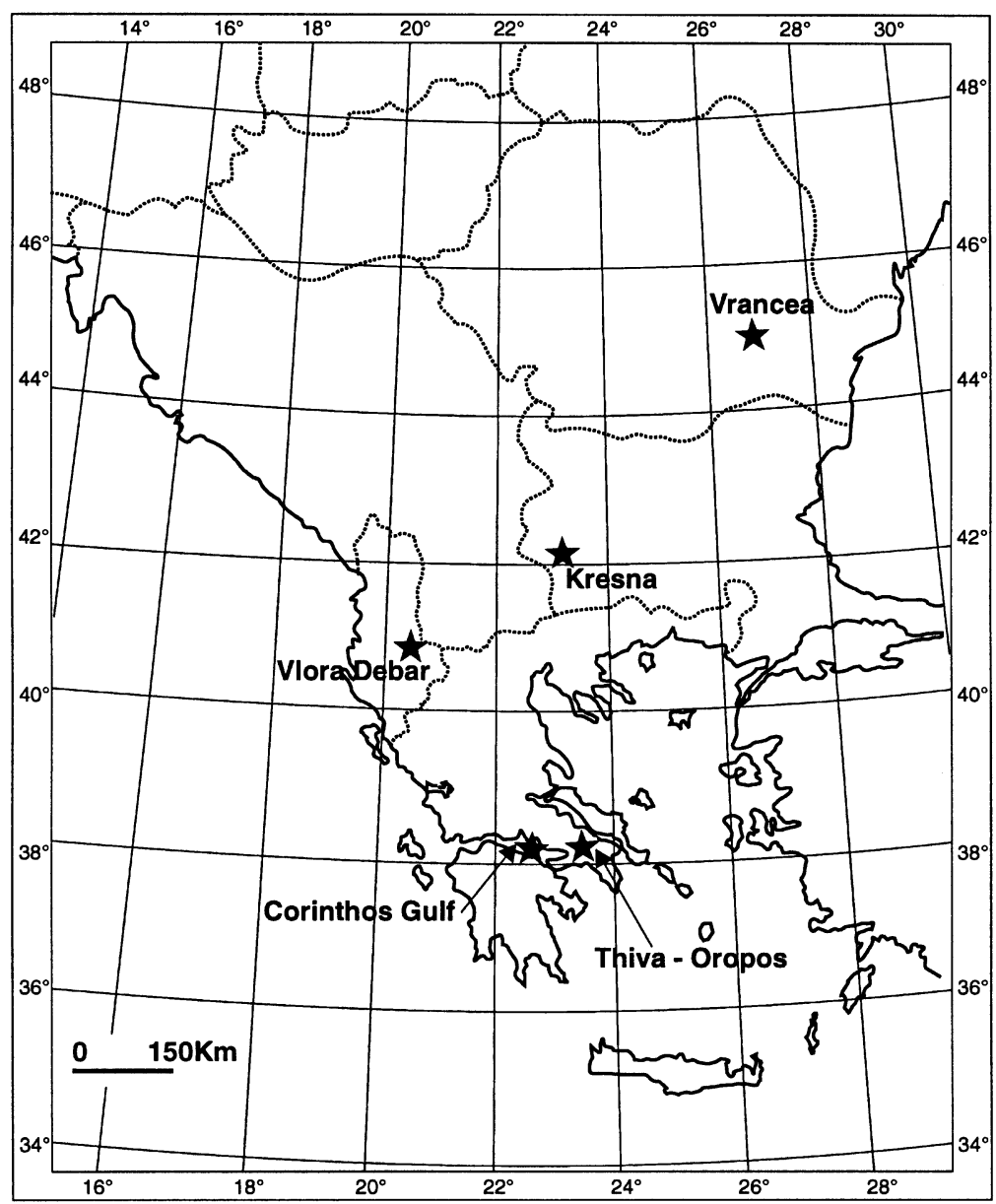

Fig. 1. The ASPELEA project test-sites of Thiva-Oropos and Corinthos Gulf (Greece), Vlora-Debar (Albania), Kresna (Bulgaria) and Vrancea (Romania). The catastrophic earthquake of 7 September 1999 took place in the geographical area of the Thiva-Oropos active seismic zone (see Figs. 2 and 3 for details).

Table 1. Strong $(M s>=6.0)$ instrumental shocks in the Thiva-Oropos seismic zone and adjacent regions. Parameters of the 1999 earthquake are included in Table 3. AJ97: Ambraseys and Jackson (1997), CP: Comninakis and Papazachos (1986).

\begin{tabular}{ccccccccccc}
\hline Year & Month & Day & Hour & Min & Sec & Lat & Long & $h(\mathrm{~km})$ & Ms & Ref \\
\hline 1914 & 10 & 17 & 6 & 22 & 32 & 38.3 & 23.4 & $n$ & 6.0 & CP \\
1928 & 04 & 22 & 20 & 13 & 46 & 37.9 & 23.0 & $n$ & 6.3 & CP \\
1938 & 07 & 20 & 00 & 23 & 35 & 38.3 & 23.8 & $n$ & 6.0 & CP \\
1981 & 02 & 24 & 20 & 53 & 37 & 38.1 & 22.8 & 12 & 6.7 & AJ97 \\
1981 & 02 & 25 & 02 & 35 & 54 & 38.1 & 23.1 & 8 & 6.4 & AJ97 \\
1981 & 03 & 4 & 21 & 58 & 07 & 38.2 & 23.2 & 7 & 6.2 & AJ97 \\
\hline
\end{tabular}

seismotectonics and palaeoseismology, gravity and geodetic measurements. The term "seismic potential," however, has been used in a non-standard way by several investigators and different definitions or approaches were introduced by different authors in regions of different seismotectonic environments.

\section{The Athens M5.9 Earthquake of 7 September 1999}

\subsection{Background information}

The most seismically active fault zone in the broad area of Athens is that of Thiva-Oropos trending about W-E to the north of the metropolitan area of Athens (Figs. 1 and 2). Neotectonic fault scarps clearly indicate normal faulting with fault planes dipping to the north (e.g. Mettos et al., 1986, 1992). Three strong earthquake sequences occurred 


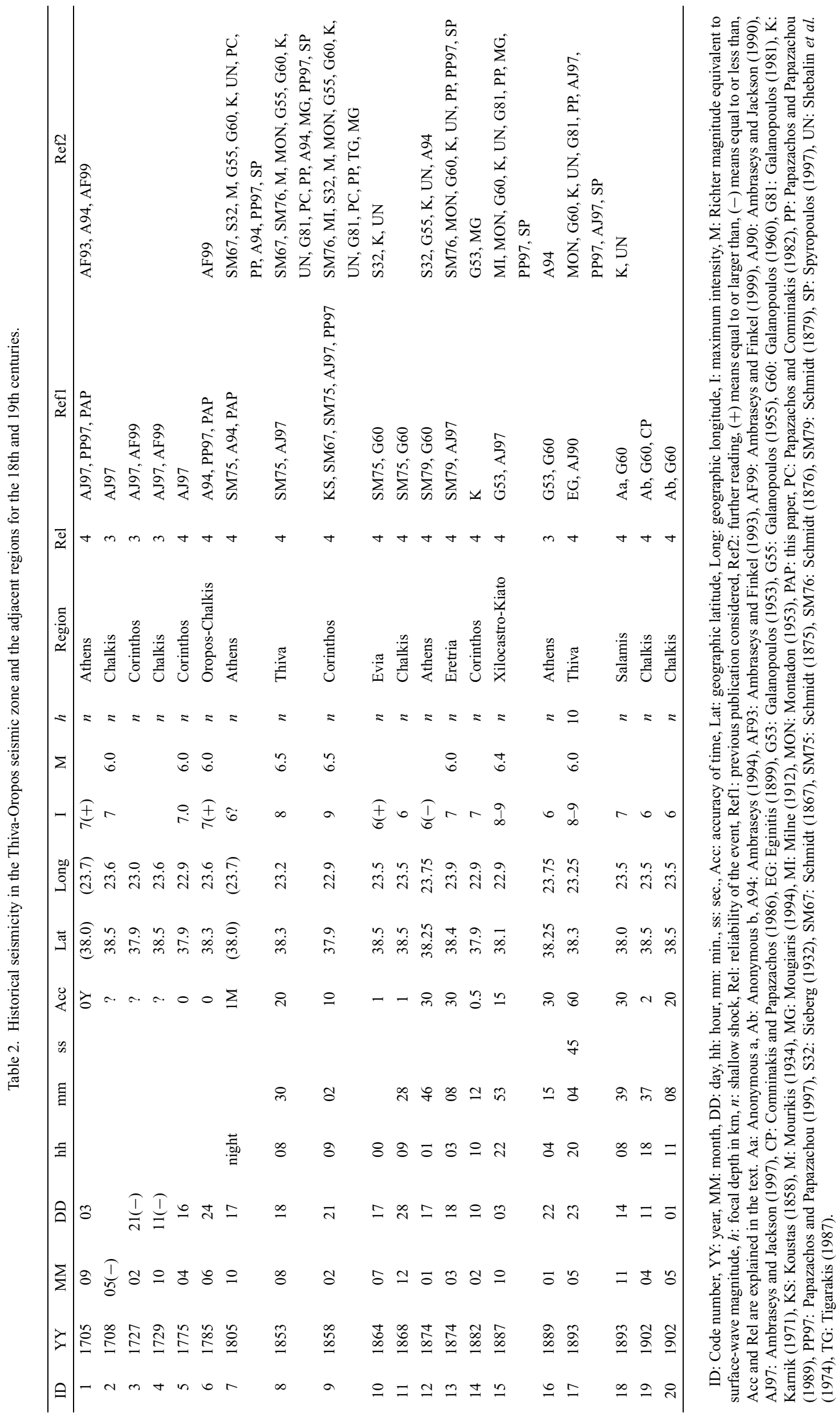




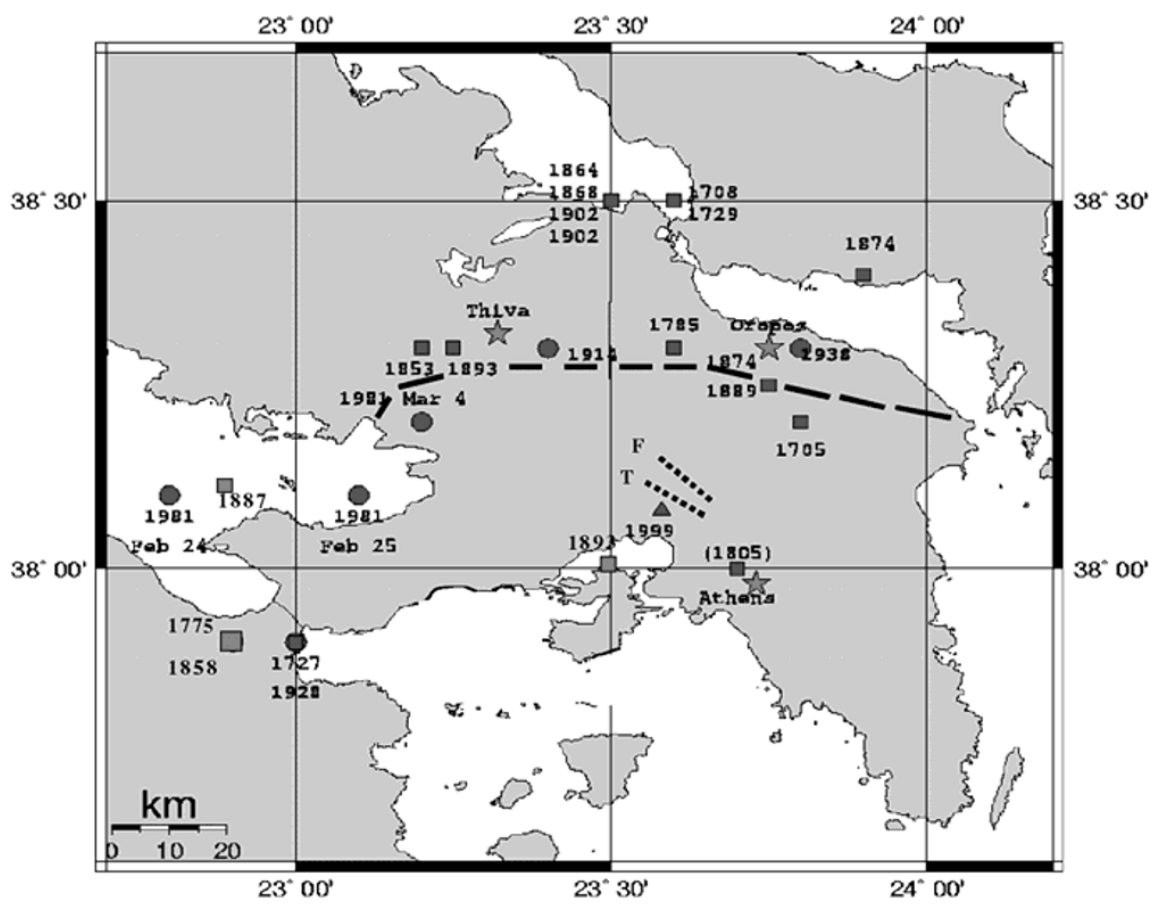

Fig. 2. The active tectonic zone of Thiva-Oropos (heavy line). Epicenters of strong shocks listed in Tables 1 and 2 are plotted. Circle: instrumental event (see Table 1), square: historical event (see Table 2), triangle: the 7 September 1999 shock (see Table 3 ). The 1805 event has been conventionally located at the historical centre of Athens for reasons explained in the text. F: Fili fault, T: Thriassion Pedion fault.

\section{Athens EQ Aftershocks 7-17/9}

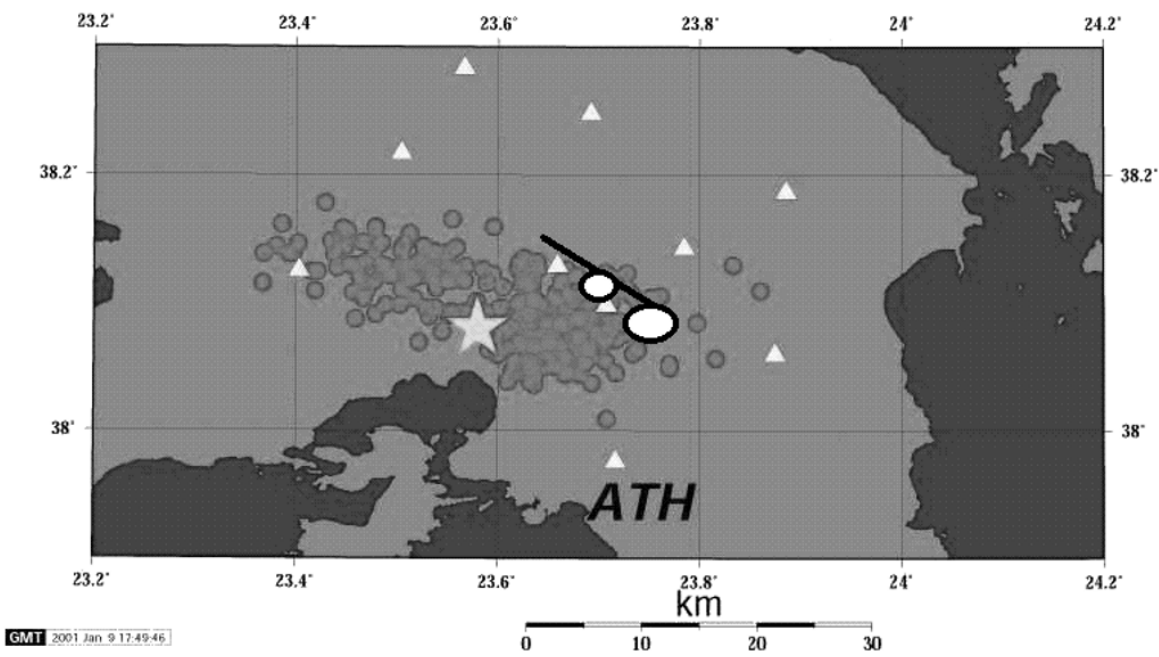

Fig. 3. Relocated epicentre of the 7 September 1999 main shock (star) and aftershocks (circles) for the period from 7 to 17 September 1999 (data from Papadopoulos et al., 2000, 2001). Triangles: seismograph stations, straight line: Fili fault, ellipses: main damage zones of VIII-IX intensity degree. The Fili Fort is located very close to the NW part of the Fili fault.

in that area during the instrumental period of observation, namely in 1914, 1938 and 1981, while another set of six strong shocks were reported during the 18th and 19th centuries (Fig. 2; see for details and references in Tables 1 and 2). The event of 4 March $1981(M s=6.2)$ was one of the two very strong aftershocks of the large $(M s=6.7)$ main shock of 24 February 1981 (Table 1). The focal mechanism of the 4 March 1981 aftershock as determined by
Jackson et al. (1982), Papazachos et al. (1984) and Taymaz et al. (1991) is compatible with the geometry and kinematics of the neotectonic fault scarps in the Thiva-Oropos zone. Focal mechanisms of smaller magnitude earthquakes, however, are not available. Since the Thiva-Oropos seismic zone constitutes a great threat for the metropolitan area of Athens, it was selected as one of the test sites (Fig. 1) of the European project ASPELEA which stands as an acronym of 
Table 3. Parameters of the earthquake of 7 September 1999 (last line) as well as of the small shocks that were recorded in 1965 and in 1997 within a distance $D \leq 30 \mathrm{~km}$ from the epicenter of that earthquake. $\varphi_{N}^{\circ}$ : geographic latitude, $\lambda_{E}^{\circ}$ : geographic longitude, $h$ : focal depth, $n$ : shallow shock, $M s$ : surface-wave magnitude.

\begin{tabular}{ccccccc}
\hline Date & Time $(\mathrm{UT})$ & $\varphi_{N}^{\circ}$ & $\lambda_{E}^{\circ}$ & $h(\mathrm{~km})$ & $M s$ & $D(\mathrm{~km})$ \\
\hline 1965 DEC 4 & 040840.0 & 38.1 & 23.8 & $n$ & 3.5 & 8 \\
1997 NOV 4 & 103032.9 & 38.14 & 23.39 & 24 & 4.4 & 20 \\
& 103247.5 & 38.33 & 23.68 & 5 & 4.3 & 21 \\
& 104345.9 & 38.12 & 23.71 & 34 & 3.3 & 9 \\
& 111922.0 & 38.34 & 23.43 & 25 & 4.0 & 27 \\
& 133138.2 & 38.23 & 23.60 & 20 & 3.8 & 9 \\
NOV 5 & 16093.3 & 38.20 & 23.50 & 30 & 3.9 & 12 \\
& 102754.0 & 38.24 & 23.52 & 26 & 4.5 & 13 \\
& 103153.7 & 38.26 & 23.49 & 20 & 4.4 & 17 \\
& 103522.9 & 38.17 & 23.58 & 25 & 4.2 & 4 \\
& 115733.7 & 38.11 & 23.57 & 38 & 3.8 & 6 \\
& 141136.4 & 38.28 & 23.45 & 5 & 3.5 & 21 \\
& 202535.4 & 38.19 & 23.39 & 5 & 3.6 & 21 \\
NOV 6 & 170712.6 & 38.22 & 23.64 & 26 & 3.3 & 8 \\
& 174715.1 & 38.18 & 23.50 & 22 & 3.8 & 11 \\
& & & & & & \\
\hline
\end{tabular}

"Assessment of Seismic Potential in European Large Earthquake Areas."

The moderate-to-strong $(M s=5.9)$ earthquake that hit the metropolitan area of Athens on 7 September 1999 was the most important, disastrous earthquake in modern history of Greece. Although the earthquake occurred geographically close to the well-known Thiva-Oropos seismic zone (Fig. 2), the 1999 earthquake seems to be related to another seismogenic structure, which probably is associated with a local fault segment of rather small length lying about 30 $\mathrm{km}$ to the south of that zone. The main shock $(M s=5.9$, NOAGI; $M w=5.9$ and $M o=7.8 \times 10^{17} \mathrm{Nm}$, USGS) took place at 11:56:50.5 GMT, at a distance of $\sim 18 \mathrm{~km} \mathrm{NW}$ from the historical centre of Athens (Table 3) (Figs. 2 and 3). It was the first seismic event ever reported to have caused casualties within the Athens urban area. About 100 buildings were totally collapsed (see examples in Figs. 4 and 5) causing 143 casualties while another 800 injured. About 65,000 buildings suffered heavy or moderate damage. The first days after the shock about 100,000 people rendered homeless. The tangible loss caused exceeds $3 b$ US\$, and from this point of view it was the worst natural disaster in modern history of Greece.

The main shock was preceded by four immediate foreshocks with $M_{L} 3.2,2.5,2.5$ and 3.2 being recorded within 18 to 2 minutes before the main shock occurrence. More than 1,500 aftershocks were located from the recordings of a local array of portable instruments deployed in the earthquake area by the National Observatory of Athens, Institute of Geodynamics (NOAGI), immediately after the earthquake occurrence (Fig. 3).

\subsection{The seismic potential in the Athens earthquake re- gion}

In this section instrumental and historical seismicity are examined to show why such a disastrous event, occurring only $18 \mathrm{~km}$ from the historical centre of Athens, was not expected even in the long-term sense. Then, we review new data collected after the Athens 1999 earthquake and examine how they can affect our consideration about the seismic potential of the particular region. For understanding why the seismic potential was considered to be very low before the Athens earthquake, two types of information should be taken into account; past seismicity and active tectonics.

\subsubsection{Past Seismicity}

\section{A. Instrumental earthquakes}

During the instrumental observation era no considerable seismic activity was observed before the 1999 shock. Only small magnitude earthquakes were recorded from time to time like those of 3 April $(M s=4.25)$ and 4 December $(M s=3.5) 1965$ and the cluster of fourteen earthquakes with $M s$ ranging from 3.8 to 4.5 that occurred in the 3-day interval of 4-6 November 1997 (Table 3). The strongest shocks $(M s=6.0)$ recorded in the Thiva-Oropos zone and its adjacent regions in the instrumental observation era are listed in Table 1 and plotted in Fig. 2.

B. Historical earthquakes

Studying historical seismicity is of importance for a reliable seismic potential assessment since it offers evidence for the long-term earthquake activity. Therefore, an effort was made to compile a new historical earthquake catalogue of the Thiva-Oropos seismic zone and its adjacent regions. Previous catalogues, scientific papers, reports, books and two unpublished earthquake archives of NOAGI, covering 


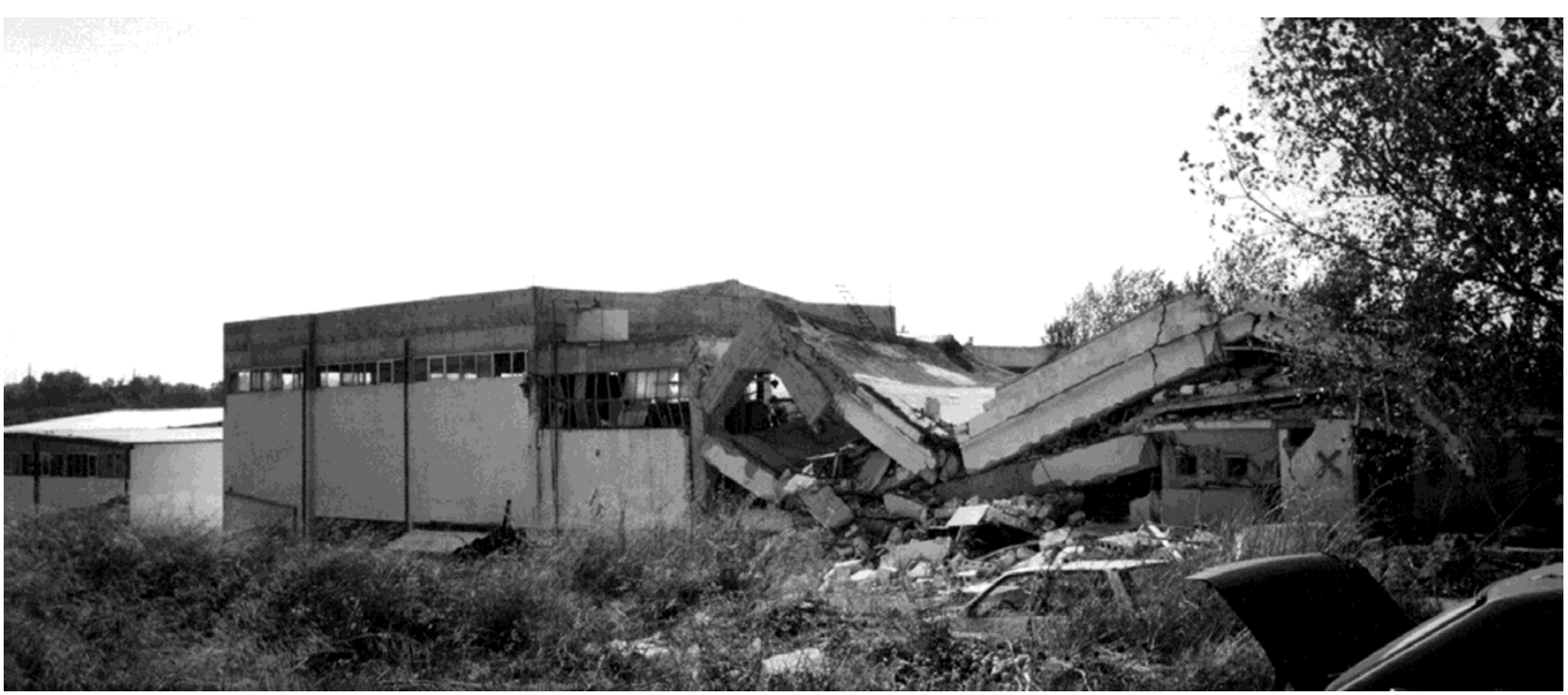

Fig. 4. Collapse of a reinforced-concrete factory in the region of Aharnes (large ellipse in Fig. 3).

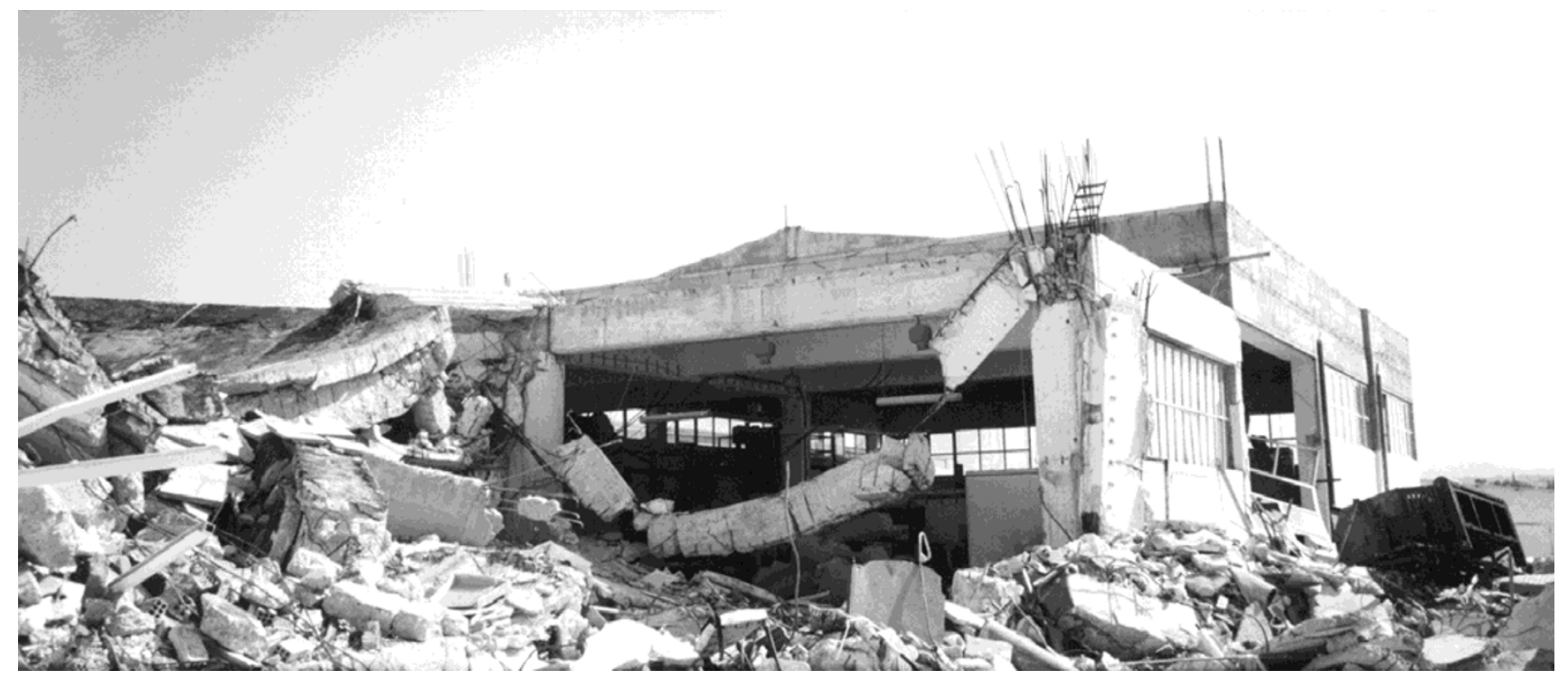

Fig. 5. Collapse of a reinforced-concrete factory located next to that shown in Fig. 4.

the time periods from 1893 to 1901 and from 1902 to 1915 inclusive, were used as data sources. For every strong earthquake event reported in the above mentioned sources, several parameters were estimated in the catalogue as shown in Table 2. As for the origin time, the epicentral coordinates, the maximum intensity reported and the estimated Richter magnitude, an evaluation was made based on the respective sets of parameters determined by previous authors. For each event the best set of parameters was chosen by combining the reports of more than one authors indicated by Ref1 in Table 2. The 1708 and 1727 events were reported only by Ambraseys and Jackson (1997) and Ambraseys and Finkel (1999) and, therefore, their determinations were adopted. The epicenters of the earthquakes listed in Table 2 are plotted in Fig. 2. The epicenter of the 1805 earthquake is tenta- tively plotted in Athens where the earthquake was felt without any further indication about the possible earthquake epicenter.

In Table 2, two reliability parameters, Acc and Rel, are shown for each event. Acc indicates the accurracy of the origin time measured in units of the last entry of the time of occurrence. When the Acc indication is followed by $\mathrm{Y}$ or $\mathrm{M}$, the accuracy unit is one year or one month, respectively. Rel measures the reliability of the earthquake occurrence itself. A scale ranging from 0 to 4 has been constructed to represent the reliability of an earthquake occurrence; $0=$ very improbable earthquake, $1=$ improbable earthquake, 2 = questionable earthquake, $3=$ probable earthquake and $4=$ definite earthquake.

Additional evidence for strong earthquake occurrences in 


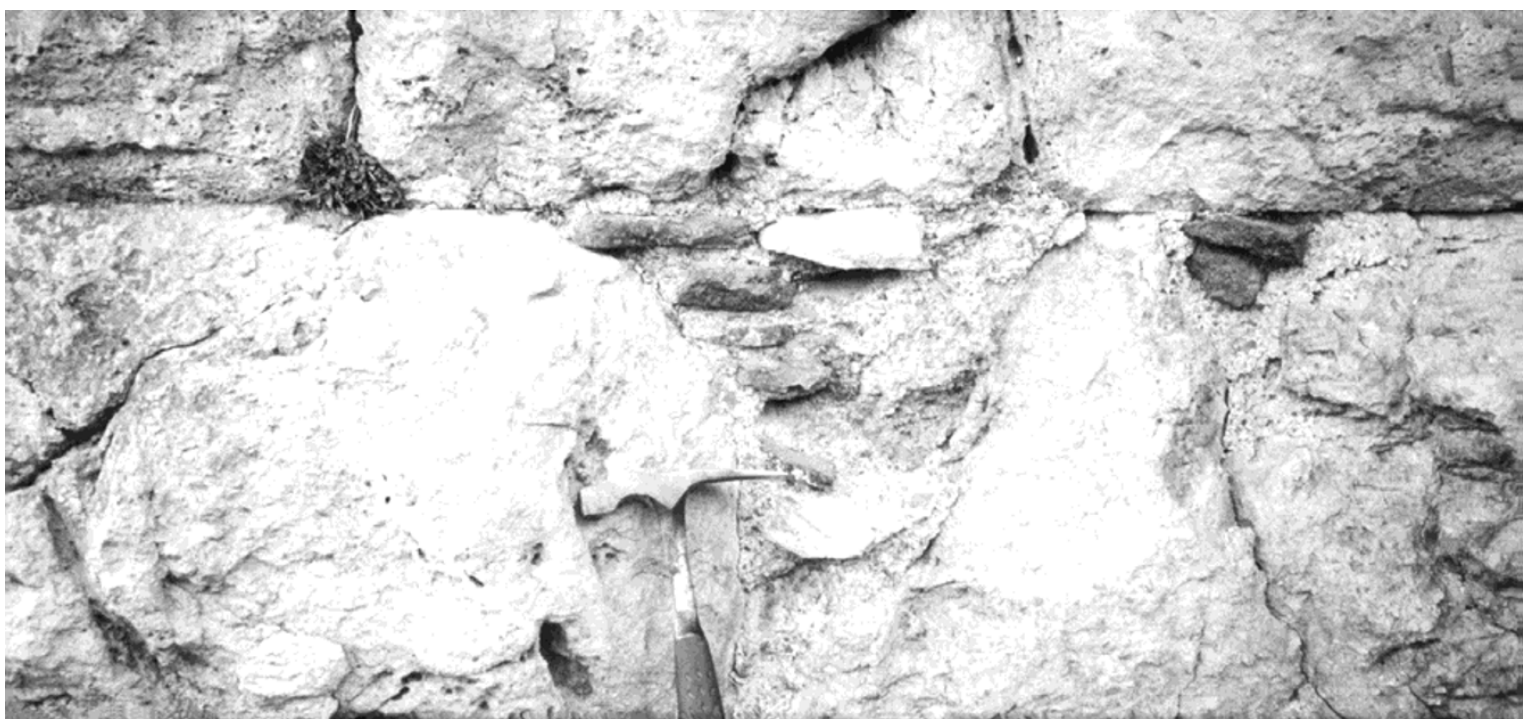

Fig. 6. Old reparation works in broken wall-stones in the Fili Fort. Reparation consists of bricks soldered by mortar.

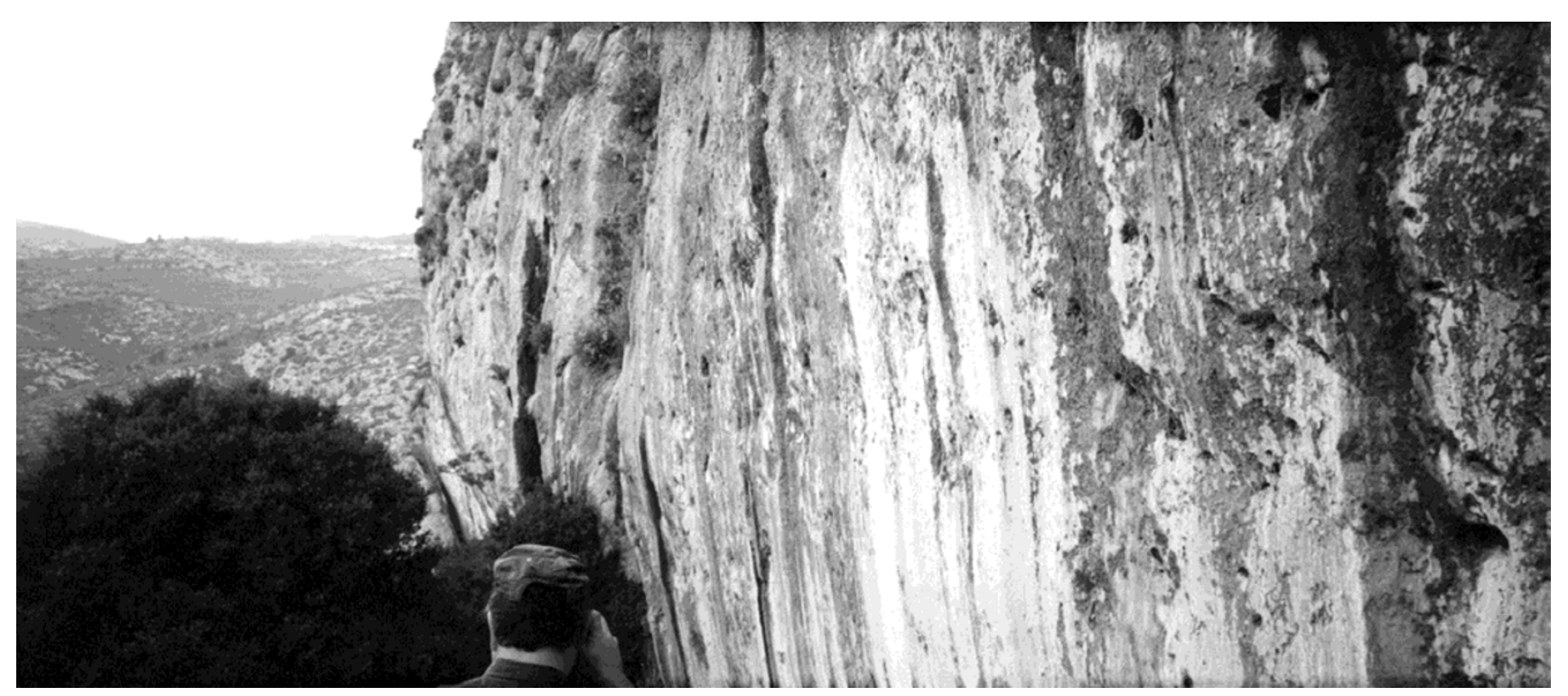

Fig. 7. Polished surface of the Fili neotectonic fault.

the Thiva-Oropos zone comes from archaeological investigations. Excavations in a palatial workshop at Thiva indicated that an earthquake is the likely cause of the destruction that occurred in the 13th century B.C., that is in LH IIIB period, while another destruction, probably of seismic origin, occurred again in Thiva at the end of the 3rd millenium B.C. or EH period (Sampson, 1996).

One of the heavily damaged structures because of the 1999 catastrophic earthquake in Athens was the Fili Fort established in the 4th century B.C. The Fort, being located about $20 \mathrm{~km}$ to the north of the historical centre of Athens, is very close to the northern segment of the Fili fault (Fig. 3). This monument is structured by marble blocks of about $60 \mathrm{~cm} \times 30 \mathrm{~cm} \times 50 \mathrm{~cm}$ in dimension. Wall collapse as well as cracks, rotations and falls of structural elements were observed. Characteristic breaks and separation of the broken parts occurred in several structural blocks. Of great interest is that reparation works were observed (Fig. 6) in similar, past breaks and separations in structural blocks, which may imply a damage from past earthquake(s). Reparation consists of bricks soldered by mortar. The bricks used probably represent palaeochristianic or Byzantine era. Further research deserves to be made to identify the earthquake event(s) that caused the repaired damage.

3.2.2 Field observations and active tectonics Field geological observations performed at the Fili normal fault after the earthquake of 7 September 1999 revealed the existence of steep scarps, indicating neotectonic and possibly active fault slips, and especially polished fault surfaces cutting mainly through basement crystalline limestone and occasionally through cemented limestone breccia. The polished surfaces, observed not only on the master neotectonic fault 
(Fig. 7), but also on blocks separated from the fault surface because of the Athens earthquake, imply very young normal reactivation striking $\mathrm{N} 110^{\circ}-130^{\circ}$ and dipping $\mathrm{SW} 70^{\circ}-$ $80^{\circ}$ (see also in Pavlides et al., 1999). Teleseismic (USGS, Harvard, Caltech, Mednet, Papadimitriou et al., 2000) and near-field (NOAGI) fault plane solutions of the main shock imply that it was associated with a normal faulting trending WNW-ESE and dipping about $56^{\circ}$ to SSW (Papadopoulos et al., 1999, 2000). This solution is consistent with the geometry of the aftershock area and implies that the Fili neotectonic fault (Figs. 2 and 7) possibly represents the surface expression of the seismogenic structure. In fact, downwards displacements of 1-6 $\mathrm{cm}$ of the hanging-wall, observed at three different positions of the Fili fault on the first day after the earthquake of 7 September 1999, indicate a marginal surface fault break associated with the main shock faulting. Moreover, the meizoseismal area of the earthquake (Fig. 3) is located in the hanging-wall domain of the Fili fault, and other important ground failures, like local landslides, block separations and rock falls, are concentrated along or very close to the Fili fault. Besides, the geometry of the fault is consistent with the geometry of the aftershock area and with the position of the relocated main shock focus which is placed at about $10 \mathrm{~km}$ to the southwest of the fault line with a focal depth of $17 \mathrm{~km}$ (Fig. 8).

The above observations make quite possible that the Fili fault constitutes the main seismogenic structure associated with the rupture of 7 September 1999. On the contrary, another fault in the aftershock area, that of Thriassion Pedion (Fig. 2), is not likely to be the source of the main rupture. Field inspection showed no evidence of surface displacements or other ground failures caused by the earthquake. Besides, the fault geometry does not fit the aftershock distribution and the relocated main shock focus.

From the previous analysis and the data listed in Table 2 it is evident that several strong, historical earthquake events were reported in the broad area of Athens, which could be

\section{0-day Aftershock Sequence}

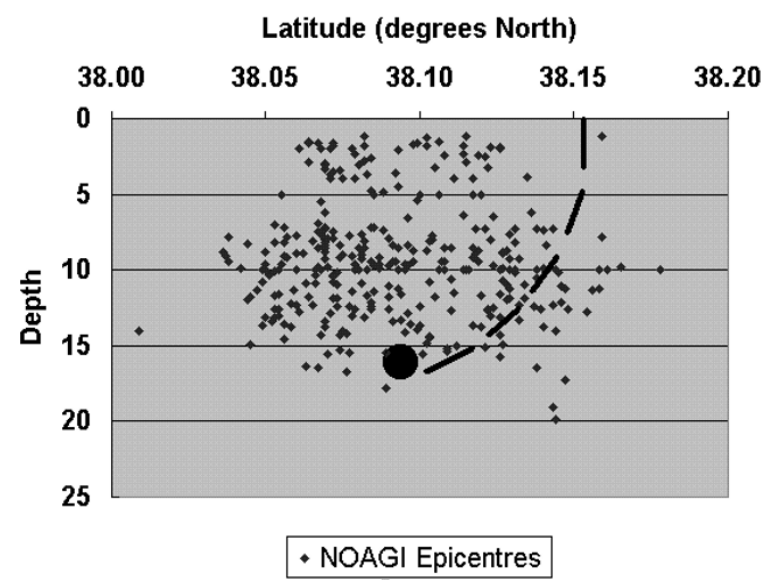

Fig. 8. Foci of the 10-day aftershocks plotted in Fig. 3 in a N-S section. Circle represents the relocated main shock while dashed line is a suggested illustration of the Fili fault. Horizontal scale doubles that of vertical scale. associated either with the Thiva-Oropos fault system or even with the Fili fault. For example, the events of 1705, 1805 and 1889 could be tentatively located at a distance of about $30 \mathrm{~km}$ from the center of Athens; however, the little macroseismic information available makes their epicentral locations very uncertain. The epicenter of $38.3^{\circ} \mathrm{N}, 24.0^{\circ} \mathrm{E}$ and the magnitude of $M s=6.4$ suggested by Papazachos and Papazachou (1997) for the 1705 earthquake are not justified by the existing macroseismic data that include only one observation point in Athens (see Lambros, 1881 for original Greek text, and Ambraseys and Finkel, 1993 for an English version of it). On the other hand, field observations indicate that the Fili fault reactivated in very recent geological time, possibly within the historical period, but this fact revealed only after the occurrence of the Athens strong earthquake of 1999.

\section{Discussion and Conclusion}

In view of seismic potential assessment some important lessons were learned from the catastrophic earthquake of Athens.

First, the 1999 earthquake was unexpected in the sense that it took place in a region traditionally believed to be of very low seismic potential. This belief was simply based on that past strong earthquakes were not documented to have ruptured the region. The scientific community, however, neglected to organize or at least to propose more systematic investigations regarding the seismic potential of the area situated only $20 \mathrm{~km}$ from the historical center of the capital city of a highly seismogenic country. The small magnitude earthquakes recorded from time to time did not attract the interest towards a more detailed examination of the seismicity of the area. Nor the active tectonics of the area was studied, the only "approach" being mapping of faults in geological maps of 1:50,000 scale. The geologically very young reactivations of the Fili neotectonic fault were revealed only after the 1999 earthquake occurrence. Therefore, the earthquake was generated from a previously unidentified seismogenic structure. Obviously this is a typical example of the classical way of seismologists' thinking that only the high seismicity regions are of interest. The case of the Athens 1999 earthquake, however, indicates that the low rate of instrumental seismicity is not a safe criterion to evaluate the seismic potential. Other approaches, like tectonic analysis, historical seismicity, geodesy and gravimetry have proved to be of remarkable importance in studies of this type. Should a research effort had been undertaken before 1999, it certainly would have revealed that the neotectonic Fili fault is active, that at least one strong earthquake occurred on it in historical times and that strong shocks should be expected in the future.

Second, although the 1999 earthquake was of moderateto-strong size, the occurrence of such an earthquake very close to a large urban area, like the metropolitan area of Athens, turned it to be a catastrophic shock. A few years ago, Papadopoulos and Arvanitides (1996) evaluated the earthquake risk in the several seismogenic segments of Greece, considering the risk as a convolution of seismic hazard, vulnerability and economic value exposed to the hazard. The result was rather impressive. The Athens region, in spite 
of relatively low seismic hazard, was put at the top of the risk scale because of its very high value and vulnerability. The meaning is clear; even a moderate earthquake could produce extensive catastrophic consequences. This was exactly the case of the 1999 earthquake.

Third, there is no doubt that a systematic study is needed for all possible seismogenic structures in the Athens region. Earthquakes of a size comparable to that of 1999 could be generated in the future not only in the Thiva-Oropos zone but also in other seismogenic structures not yet identified. Now, the forthcoming Olympiad of 2004 makes one more important reason to drastically increase the scientific knowledge about the seismic phenomena in the metropolitan area of Athens.

Acknowledgments. This study has been performed within the frame of ASPELEA Research Project supported by EU-DGXII, Inco-Copernicus Program, contract no. IC-15CT-97-0200 and partly by the General Secretary of Research and Technology, Greece and the Earthquake Planning and Protection, Greece. We express our sincere thanks to two anonymous reviewers for their suggestions that helped to improve the original manuscript.

\section{References}

Ambraseys, N. N., Material for the investigation of the seismicity of Central Greece, in Historical Investigation of the Seismicity of European Earthquakes, vol. 2, edited by P. Albini and A. Moroni, pp. 1-10, 1994.

Ambraseys, N. N. and C. Finkel, Material for the investigation of the seismicity of the Eastern Mediterranean region during the period 1690 1710, in Historical Investigation of European Earthquakes, vol. 1, edited by M. Stucchi, pp. 173-194, 1993

Ambraseys, N. N. and C. Finkel, Unpublished Ottoman archival information on the seismicity of the Balkans during the period 1500-1800, in Natural Disasters in the Ottoman Empire, Institute for Mediterranean studies, Halcyon Days in Crete III, A Symposium held in Rethymnon, 10-12 January 1997, pp. 89-107, Crete University Press, 1999.

Ambraseys, N. N. and J. A. Jackson, Seismicity and associated strain of central Greece between 1890 and 1988, Geophys. J. Int., 101, 663-708, 1990.

Ambraseys, N. N. and J. A. Jackson, Seismicity and strain in the Gulf of Corinth (Greece) since 1694, J. Earthq. Eng., 1, 433-474, 1997.

Anonymous a, Book of the earthquakes observed in Greece in the time interval 1893-1901, Insitute of Geodynamics, National Observatory of Athens, $181 \mathrm{pp}$. (Manuscript in Greek).

Anonymous b, Book of the earthquakes in Greece in the time interval 1902-1915, Institute of Geodynamics, National Observatory of Athens, 399 pp. (Manuscript in Greek).

Coburn, A. and R. Spence, Earthquake Protection, John Wiley, England, pp. 355, 1992.

Comninakis, P. E. and B. C. Papazachos, A catalogue of earthquakes in Greece and the surrounding area for the period 1901-1985, Univ. Thessaloniki Geophys. Lab. Publ., 1, 167, 1986.

Cornell, C. A., Engineering seismic risk analysis, BSSA, 58, 1583-1606, 1968.

Eginitis, D. (Publ.), Annales de l'Observatoire National d'Athènes, tome II, 346 pp., 1899.

Fedotov, S. A., Regularities in the distribution of strong earthquakes in Kamchatka, the Kuril Islands and northeastern Japan, Akad. Nauk. SSSR Inst. Fiziki Zeml: Trudy, 36, 66-93, 1965.

Galanopoulos, A. G., Katalog der Erdbeben in Griechland für die zeit von 1879 bis 1892, Ann. Geol. Pays Hellen., 5, 144-229, 1953.

Galanopoulos, A. G., The Seismic Geography of Greece, Ann. Geol. Pays Hellen., 6, 83-121, 1955 (in Greek).

Galanopoulos, A. G., A catalogue of shocks with $I o \geq V I$ or $M \geq 5$ for the years 1801-1958, Seismol. Lab. Univ. Athens, 1960.

Galanopoulos, A. G., The earthquake potential of Greece, Ann. Geol. Pays Hellen., 30, 648-724, 1981 (in Greek).

Ganse, R. A. and J. B. Nelson, Catalog of Significant Earthquakes, 2000 B.C.-1979, World Data Center A for Solid Earth Geophysics-NOAA, Report SE-27, 1979.

Iida, K., Earthquake magnitude, fault and source dimensions, J. Earth Sci.,
13, 115-132, 1965.

Jackson, J. A., J. Gagnepain, G. Houseman, G. C. P. King, P. Papadimitriou, C. Soufleris, and J. Virieux, Seismicity, normal faulting and the geomorphological development of the Gulf of Corinth (Greece): the Cotinth earthquakes of February and March 1981, Earth Planet. Sci. Lett., 57, 377-397, 1982.

Kagan, Y. Y. and D. D. Jackson, Seismic gap hypothesis: Ten years after, $J$. Geophys. Res., 96, 21419-21431, 1991.

Karnik, V., Seismicity of the European Area, Part II, 1801-1900, 218 pp., D. Reidel Publ. Comp. Dordrecht, The Netherlands, 1971.

Kelleher, J., L. R. Sykes, and J. Oliver, Possible criteria for predicting earthquake locations and their application to major plate boundaries of the Pacific and the Caribbean, J. Geophys. Res., 78, 2547-2585, 1973.

Koustas, G., Earthquake of Corinth, Pandora, 15 August 1858, 225-229, 1858 (in Greek).

Lambros, S. P., The earthquakes in Athens before 1821, Estia, 280, 289291, 1881 (in Greek).

McCann, W. R., S. P. Nishenko, L. R. Sykes, and J. Krause, Seismic gaps and plate tectonics: seismic potential for major boundaries, Pure and Applied Geophys., 117, 1082-1147, 1979.

McGuire, R. K., Fortran computer program for seismic risk analysis, U.S.G.S. Open-File Rep. 76-67, 1978.

McGuire, R. K., (Ed.), The practice of earthquake hazard assessment, IASPEI-ESC, 1-284, 1993.

Mettos, A., Ch. Ioakim, and Th. Rondoyanni, Les Formations neogenes lacustres de 1'Attique du Nord-Beotie: stratigraphie, palynologie et tectonique, Geologie Mediterraneenne, 12-13, 167-174, 1986.

Mettos, A., Th. Rondoyanni, Ch. Ioakim, and I. Papadakis, Evolution geodynamique et reconstruction paleoenvironnementale des basins neogenes-quaternaires de la Grece centrale, Palaeontologia I Evolucio, 2425, 393-402, 1992.

Milne, J., Catalogue of destructive earthquakes. "Report of the 18th meeting of the British Association for the advancement of science, Portsmouth, 1911", 649-740, London, 1912.

Mogi, K., Some features of recent seismic activity in and near Japan (1), Bull. Earthq. Res. Inst., 46, 1225-1236, 1968.

Montadon, Les tremblements de terre destructeurs en Europe, pp. 195, Geneve, 1953.

Mougiaris, N. K., Seismic history of the Aegean area, Thesis, Univ. of Patras, 439 pp., 1994.

Mourikis, M. D., The earthquakes in Greece from ancient time till now, 68 pp., Sarris Publ., Athens, 1934 (in Greek).

Nishenko, S. P., Seismic potential for large and great interplate earthquakes along the Chilean and southern Peruvian margins of South America: A quantitative reappraisal, J. Geophys. Res., 90, 3589-3615, 1985.

Nishenko, S. P., Earthquakes: Hazards and predictions, in The Encyclopedia of Solid Earth Geophysics, edited by D. E. James, pp. 260-268, Van Nostrand Reinhold, New York, 1989.

Nishenko, S. P., Circum-Pacific seismic potential: 1989-1999, Pure Appl. Geophys., 135, 169-259, 1991.

Nishenko, S. P. and W. R. McCann, Seismic potential for the world's major plate boundaries, in Earthquake Prediction: An International Review, Maurice Ewing Ser., 4, edited by D. W. Simpson and P. G. Richards, pp. 20-28, AGU, Washington, 1981.

Nishenko, S. P. and L. R. Sykes, Comment on 'Seismic gap hypothesis: Ten years after' by Y. Y. Kagan and D. D. Jackson, J. Geophys. Res., 98, 9909-9916, 1993.

Papadimitriou, P., G. Kaviris, N. Voulgaris, I. Kassaras, N. Delibasis, and K. Makropoulos, The September 7, 1999 Athens earthquake sequence recorded by the Cornet network: preliminary results of source parameters determination of the main shock, Ann. Geol. Pays Hellen., 38, 2939, 2000.

Papadopoulos, G. A. and A. Arvanitides, Earthquake risk assessment in Greece, in Earthquake Hazard and Risk, edited by V. Schenk, pp. 221229, Kluwer Academic Publishers, The Netherlands, 1996.

Papadopoulos, G. A., I. Baskoutas, G. Chouliaras, G. Drakatos, I. Kalogeras, V. Karastathis, M. Kourouzidis, I. Latoussakis, D. Makaris, N. Melis, G. Panopoulou, D. Papanastassiou, I. Pappis, S. Tassos, A. Plessa, and G. Stavrakakis, Seismological aspects of the Athens earthquake of 7th September, 1999: Preliminary results. 1st Conf. "Advances on Natural Hazards Mitigation-Experiences from Europe and Japan", Programme, Abstractes, Reports, Athens 3-4 November, 1999, Santorini 5-7 November, 1999, 73-79.

Papadopoulos, G. A., G. Drakatos, D. Papanastassiou, I. Kalogeras, and G. Stavrakakis, Preliminary results about the catastrophic earthquake of 
7 September 1999 in Athens, Greece, Seismol. Res. Lett., 71, 318-329, 2000

Papadopoulos, G. A., G. Drakatos, D. Papanastassiou, I. Kalogeras, and G. Stavrakakis, Preliminary results about the catastrophic earthquake of 7 September 1999 in Athens, Greece: ERRATUM, Seismol. Res. Lett., 72, 73, 2001.

Papazachos, B. C. and P. E. Comninakis, A catalogue of historical earthquakes in Greece and surrounding area: 479B.C.-1900A.D., Geophys. Lab. Univ. of Thessaloniki Publ., 5, 1-24, 1982.

Papazachos, B. C. and K. Papazachou, The Earthquakes of Greece, 347 pp., Ziti, Thessaloniki, 1989 (in Greek).

Papazachos, B. C. and C. B. Papazachou, The Earthquakes of Greece, 304 pp., Zitti Publ., Thessaloniki, 1997.

Papazachos, B. C., P. E. Comninakis, E. E. Papadimitriou, and E. M. Scordilis, Properties of the February-March 1981 seismic sequence in the Alkionides gulf of central Greece, Ann. Geophys., 2, 537-544, 1984

Pavlides, S., G. A. Papadopoulos, and A. Ganas, The 7th September, 1999 unexpected earthquake of Athens: Preliminary results on the seismotectonic environment. 1st Conf. "Advances on Natural Hazards MitigationExperiences from Europe and Japan", Programme, Abstractes, Reports, Athens 3-4 November, 1999, Santorini 5-7 November, 1999, 80-85.

Sampson, A., Cases of earthquakes at Mycenaean and Pre-Mycenaean Thebes, in Archaeoseismology, edited by S. Stiros and R. E. Jones, pp. 113-117, 1996.

Schenk, Vl., Achievements and probable trends in seismic hazard assessment, Tectonophys., 167, 157-169, 1989.

Schmidt, J., A study about the Aeghion earthquake of 26 (14) December 1861, Athens, 52 pp., 1867 (Greek transl. of the German text).

Schmidt, J., Studien über Erdbeben, 324 pp., Carl Scholtze, Leipzig, 1875. Schmidt, J., About earthquakes in Greece, Estia, 1, 119-122, 1876.

Schmidt, J., Studien über Erdbeben, 360 pp., Carl Scholtze, Leipzig, 1879.
Shebalin, N. V., V. Karnik, and D. Hadzievski, (Eds.), Catalogue of Earthquakes. Part II, prior to 1901. UNDP/UNESCO Survey of the Seismicity of the Balkan Region, Skopje, 1974.

Sieberg, Erdbebengeographie, pp. 1202, Verlag von Gustav Fischer, Berlin, 1932.

Slemmons, D. B., Faults and earthquake magnitude, in State-of-the-art for Assessing Earthquake Hazards in the United States, U.S. Army Eng. Waterways Exper. St. Mis. Pap. S-73-1, Rep. 6, 129 pp., 1977.

Spyropoulos, P. J., Chronicle of the earthquakes in Greece from the ancient time till now, 453 pp., 1997 (in Greek).

Taymaz, T., J. Jackson, and D. McKenzie, Active tectonics of the north and central Aegean Sea, Geophys. J. Int., 106, 433-490, 1991.

Tiedemann, H., Catalogue of Earthquakes and Volcanic Eruptions, Swiss Re, Zurich, 94 pp., 1991.

Tigarakis, G., The large earthquakes in Corinthia since ancient times, Deltio tou Syllogou Politikon Mihanikon Ellados, 182, 44-49, 1987 (in Greek).

Wallace, R. E., J. F. Davis, and K. C. McNally, Terms for expressing earthquake potential, prediction, and probability, Bull. Seismol. Soc. Am., 74, 1819-1825, 1984.

Wesnousky, S. G., C. H. Scholz, K. Shimazaki, and T. Matsuda, Integration of geological and seismological data for the analysis of seismic hazard: a case study of Japan, Bull. Seismol. Soc. Am., 74, 687-708, 1984.

Working Group on California Earthquake Probabilities, Probabilities of large earthquakes in the San Francisco Bay region, California, U.S. Geological Survey Circular 1053, 51 p., 1990.

Wyss, M., Estimating maximum expected magnitude of earthquakes from fault dimension, Geology, 7, 336-340, 1979.

G. A. Papadopoulos (e-mail: g.papad@egelados.gein.noa.gr), A. Ganas, and S. Pavlides 